\title{
Utilizing a Novel Fungal Enzymatic Cocktail as an Eco- Friendly Alternative for Cellulose Pulp Biobleaching
}

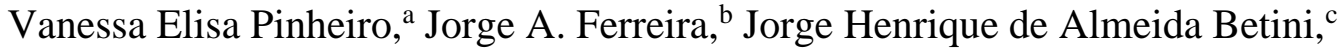 \\ Eliana Setsuko Kamimura, ${ }^{d}$ and Maria de Lourdes Teixeira de Moraes Polizeli ${ }^{\text {a,c* }}$ \\ Enzyme cocktails can alter the lignin and hemicellulose content in wood \\ cell walls, improving the bleaching process during pulp production and \\ offsetting the need for toxic chemicals. In this study, brown pulp was \\ biobleached with a mixture of crude fungal extracts rich in xylanase and \\ laccase, respectively produced from Aspergillus tamarii Kita and Trametes \\ versicolor on waste materials. The optimal conditions for biobleaching \\ were a mixture of xylanase and laccase crude extracts ( 1 to $2 \mathrm{v} / \mathrm{v}$ ), at a \\ temperature of $36{ }^{\circ} \mathrm{C}$ and a $\mathrm{pH}$ of 5.5 . The treated brown cellulose pulp \\ showed a reduction in the Kappa number by 1.83 points, representing an \\ efficiency of $20.3 \%$. In addition, the brightness increased by 4.65 points in \\ comparison to the control. Hence, studies involving the application of the \\ standardized cocktail during the hydrolysis of lignocellulosic residues, e.g., \\ barley residue and sugarcane bagasse, led to the formation of $85 \mathrm{~g} / \mathrm{L}$ and \\ $25 \mathrm{~g} / \mathrm{L}$ of reducing sugars, respectively. Moreover, the standardized \\ cocktail caused greater deinking of the recycled paper pulp.
}

\begin{abstract}
Keywords: Enzymes; Aspergillus tamarii Kita; Trametes versicolor; Cellulose pulp; Biobleaching; Central composite design

Contact information: a: Ribeirão Preto Medical School - São Paulo University. Bandeirantes Av., 3.900, Ribeirão Preto14040-900 Brazil; b: Swedish Centre for Resource Recovery, University of Borås, Borås 50190 Sweden; c: Faculty of Philosophy, Sciences and Letters at Ribeirão Preto - São Paulo University. Bandeirantes Av., 3.900, Ribeirão 14040-901 Preto, SP, Brazil; d: Faculty of Animal Science and Food Engineering - São Paulo University. Duque de Caxias Av., 225, Pirassununga 13635-900 SP - Brazil;

* Corresponding author: polizeli@ffclrp.usp.br
\end{abstract}

\section{INTRODUCTION}

The pulp and paper industry has a challenging position concerning the environment. While this industry is based on the usage of renewable and photosynthetic resources, it still discards a large amount of effluents (over $70 \mathrm{~m}^{3}$ of wastewater is generated for each ton of processed paper, depending on the nature of the raw material) (Hubbe et al. 2016). Among the major cellulose-producing countries, Brazil is the largest eucalyptus pulp producer in the world. The country stands out worldwide in terms of producing and suppling markets with substantial pulp volumes (CNI 2014).

Due to the versatility in dealing with different raw materials, the kraft (sulfate) process is the dominant chemical pulping method. The recalcitrant lignins, cellulose, phenols, fatty acids, tannins, and resins from materials are washed off as black liquor during the heating step (under high alkaline $\mathrm{pH}$ and temperature conditions). The pulp produced through this process is strong but darkly colored, which is not desirable for many products. Consequently, multistep bleaching is required to achieve higher pulp brightness (Kumar et al. 2011; Sharma et al. 2020). Industries use various chemical reagents, oxidants, alkalis, and acids to bleach cellulose pulp, e.g., chlorine dioxide $\left(\mathrm{ClO}_{2}\right)$, oxygen 
$\left(\mathrm{O}_{2}\right)$, ozone $\left(\mathrm{O}_{3}\right)$, hydrogen peroxide $\left(\mathrm{H}_{2} \mathrm{O}_{2}\right)$, sodium hypochlorite $(\mathrm{NaClO})$, and sodium hydroxide $(\mathrm{NaOH})$. The deinking methods, based on chemicals, generate toxic effluents that consequently increase the chemical oxygen demand (COD) values, which result in the costly treatment of wastewater (Polizeli et al. 2005; Kaur et al. 2018; Yang et al. 2018). In the past, bleaching was performed with elemental chlorine. This was replaced by chlorine dioxide to minimize the formation of dioxins, which are organochlorine compounds that are classified as toxic, mutagenic, and bioaccumulating. Dioxins cause numerous harmful disturbances in endocrine, reproductive, nervous, and immune systems. The use of chlorine dioxide decreases water contamination; however, dioxins are not entirely eliminated from the wastewater (Ferraz 2009; Campioni et al. 2019).

Due to effluent contamination, pressure from environmental and legislative sectors have required changes in pulp and paper technologies parameters, providing a motivation to search for more eco-friendly alternatives (Birijlall et al. 2011; Campioni et al. 2019). Hence, the application of enzymes, e.g., xylanases and laccases, in the bleaching process and the use of secondary fibers, i.e., recycled paper, and agro-industrial residues, e.g., sugarcane and barley bagasse, have been considered useful and economical sources for paper making (Campioni et al. 2019; Kumar and Rani 2019; Singh et al. 2019; Sharma et al. 2020).

The xylanolytic system is composed of hydrolytic enzymes, including endoxylanase (EC 3.2.1.8), $\beta$-xylosidase (EC 3.2.1.37), $\alpha$-glucuronidase (EC 3.2.1.139), and $\alpha$-arabinofuranosidase (EC 3.2.1.55), which cooperatively convert xylan into simple sugars (Heinen et al. 2017; Polizeli et al. 2017; Pasin et al. 2020). Laccases (EC 1.10.3.2) are multicopper oxidative enzymes, which reduce $\mathrm{O}_{2}$ to $\mathrm{H}_{2} \mathrm{O}$ during phenol and similar substrates oxidation (Claus 2004). Many organisms, e.g., filamentous fungi, bacteria, and yeasts, can produce complete enzyme systems. Their extracellular biocatalysts production is of great industrial interest (Abdullah et al. 2015; Angural et al. 2020). Moreover, enzymes have been produced using agro-industrial wastes from several bioprocesses (Pinheiro et al. 2017; Polizeli et al. 2017; Pinheiro et al. 2020). Tons of lignocellulosic residues with potential use as renewable fuels, energy, and other chemicals are readily available worldwide (Ferreira-Leitão et al. 2010).

Therefore, the present work was designed to achieve the following objectives: $(i)$ to use agricultural wastes for xylanase and laccase production via Aspergillus tamarii Kita and Trametes versicolor, respectively; (ii) to optimize the brown cellulose pulp biobleaching process according to central composite design (CCD) using crude enzyme extracts; (iii) to evaluate the Kappa number, brightness, and viscosity alterations after the brown pulp biobleaching process; (iv) to investigate waste pulping processes, namely that of barley and sugarcane bagasse, through use of an optimized enzyme cocktail; and $(v)$ to deink secondary fibers (office paper) using the developed enzyme cocktail. In this context, the aim of the present study was to develop a new enzymatic cocktail produced with residues and to improve, via experimental designs, the results in cellulose bleaching industries through biological treatment instead of chemical and harmful steps.

\section{EXPERIMENTAL}

\section{Substrates}

Brown cellulose pulp, with a Kappa number of 9.0, was provided by the Fibria (Aracruz - ES/ Brazil - $19.8188^{\circ} \mathrm{S}, 40.2736^{\circ} \mathrm{W}$ ) company after the digestion (cooking) at 
a pH of 10 to 11 and a temperature of $148{ }^{\circ} \mathrm{C}$ to $150{ }^{\circ} \mathrm{C}$ for $5 \mathrm{~h}$. Barley residue (Hordeum vulgare) was supplied by Colorado ${ }^{\circledR}$ Brewery (Ribeirão Preto, SP/Brazil - 21.1704 ${ }^{\circ} \mathrm{S}$, $47.8103^{\circ} \mathrm{W}$ ) after the maturation process. Sugarcane bagasse (Saccharum officinarum) was provided by Tereos Açúcar e Energia Brasil - Guarani Group (São Paulo - SP/Brazil - $23.5505^{\circ} \mathrm{S}, 46.6333^{\circ} \mathrm{W}$ ). Both the sugarcane bagasse and barley residue samples were washed with tap water, oven-dried at a temperature of $50{ }^{\circ} \mathrm{C}$ for $24 \mathrm{~h}$, and then ground into a particle size of $2 \mathrm{~mm}^{2}$. The wastepaper was obtained from an office in the Laboratory of Microbiology and Cell Biology at the Biology Department of the Faculty of Philosophy, Sciences and Letters of Ribeirão Preto, University of São Paulo, Brazil. The waste was manually sorted to remove non-paper objects. The wastepaper was then shredded into small pieces $\left(25 \mathrm{~mm}^{2}\right)$. Cotton gin wastes were collected from the soil after harvest on a farm in Leme - SP/Brazil $-22.1892^{\circ} \mathrm{S}, 47.3978^{\circ} \mathrm{W}$. The vinasse was supplied by Biosev Company (Leme - SP/Brazil).

\section{Microorganisms}

Trametes versicolor and Aspergillus tamarii Kita were proffered by the Mycology Collection of the Microbiology and Cell Biology Laboratory from the Faculty of Philosophy, Sciences and Letters of Ribeirão Preto/ São Paulo University (Brazil), Biology Department. The fungi were maintained in the laboratory on potato dextrose agar (PDA) slants composed of the following: $20 \mathrm{~g} / \mathrm{L}$ of glucose, $15 \mathrm{~g} / \mathrm{L}$ of agar, and $4 \mathrm{~g} / \mathrm{L}$ of potato extract (CM0139 - Oxoid, Brazil). New A. tamarii Kita PDA slants were prepared via spore transfer, using a sterilized metal stick, from pre-grown slants and then incubated for $5 \mathrm{~d}$ at a temperature of $30{ }^{\circ} \mathrm{C}$. New T. versicolor PDA plates were prepared via a transfer of $25 \mathrm{~mm}^{2}$ agar plugs from pre-grown PDA fungal slants, followed by $7 \mathrm{~d}$ of incubation at a temperature of $30{ }^{\circ} \mathrm{C}$. All slants were stored at a temperature of $4{ }^{\circ} \mathrm{C}$ until use.

\section{Enzyme Preparation}

Crude laccase extract (CLE) was produced through T. versicolor. The pre-inoculum was set by the inoculation of $T$. versicolor mycelium agar plugs $\left(4 \mathrm{~cm}^{2}\right)$ into previously sterilized (at a temperature of $121{ }^{\circ} \mathrm{C}$ and a pressure of 1.5 atm for $15 \mathrm{~min}$ ) $125 \mathrm{~mL}$ Erlenmeyer flasks containing $25 \mathrm{~mL}$ of Sabouraud medium ( $4 \mathrm{~g}$ of dextrose, $1 \mathrm{~g}$ of peptone, and $100 \mathrm{~mL}$ of distilled water) with a $\mathrm{pH}$ of 6.0. The pre-inoculum was maintained under static conditions for $96 \mathrm{~h}$, at a temperature of $30{ }^{\circ} \mathrm{C}$. Subsequently, the mycelium of the $T$. versicolor grown on pre-inoculum was transferred to the $125 \mathrm{~mL}$ Erlenmeyer flasks containing $25 \mathrm{~mL}$ of distilled water and vinasse ( 1 to $5 \mathrm{v} / \mathrm{v}$ ) and $1 \%$ cotton gin waste. The culture media were incubated under static conditions at a temperature of $30{ }^{\circ} \mathrm{C}$ for $14 \mathrm{~d}$. Afterward, the culture mediums were vacuum filtered in a Büchner funnel and Whatman $\mathrm{n}^{\circ} 1$ filter paper. The filtrated was used to determine the laccase activity (Pinheiro et al. 2020).

Crude xylanase extract (CXE) was produced according to Heinen et al. (2017). The submerged fermentation $(\mathrm{SmF})$ was carried out by inoculating $1 \mathrm{~mL}$ of spore solution $\left(10^{6}\right)$ into $125 \mathrm{~mL}$ Erlenmeyer flasks previously sterilized at a temperature of $121{ }^{\circ} \mathrm{C}$ and a pressure of $1.5 \mathrm{~atm}$ for $15 \mathrm{~min}$, which contained $25 \mathrm{~mL}$ of ADAMS salt solution (Adams 1990) and $1 \%$ barley bagasse, as a carbon source.

\section{Biobleaching of the Brown Cellulose Pulp}

The CLE and CXE were used to evaluate their potential as biobleaching agents. The brown pulp samples were incubated in polyethylene bags $(20 \mathrm{~cm} \times 30 \mathrm{~cm})$ in a water 
bath at varying times, temperatures, and $\mathrm{pH}$ values (as described in the following sections). A sodium acetate buffer $(0.1 \mathrm{M})$ was used for the $\mathrm{pH}$ adjustment of the reaction mixtures containing $8 \%$ pulp. In the control experiments, the enzyme extract was replaced by distilled water. After the enzymatic hydrolysis period, the cellulose pulp was rinsed with abundant distilled water and filtered on a sieve $\left(1 \mathrm{~mm}^{2}\right.$ pore size $)$. The sheets formed after the filtration were used to perform the optical (brightness) and chemical (viscosity and Kappa number) analyses.

\section{Biobleaching Optimization via Experimental Designs}

Crude xylanase extract (CXE) and Crude laccase extract (CLE) cocktail

A $2^{2}$ central composite design (CCD) and a response surface analysis were performed to assess the effect of the CXE and CLE proportion on brown cellulose pulp biobleaching through kappa number reduction (KNR).

Independent variables were studied at three levels $(-1,0,+1)$ defined according to the $2^{2}$ experimental design, and a set of 9 experiments were carried out, four of which were central point repetitions (Table 1 ).

Table 1. Matrix (Coded Values of the Independent Variables CXE And CLE at Different Levels) and Experimental Data Recorded in Central Composite Design Setup for the Kappa Number Reduction of Brown Pulp

\begin{tabular}{|c|c|c|c|}
\hline \multirow{2}{*}{ Treatment } & \multicolumn{2}{|c|}{ Independent Variables } & \multirow{2}{*}{ KNR } \\
\cline { 2 - 3 } & CXE $(\mathrm{mL})$ & CLE $(\mathrm{mL})$ & \\
\hline 1 & $8.3(-1)$ & $5(-1)$ & 0.84 \\
\hline 2 & $18.3(+1)$ & $5(-1)$ & 1.35 \\
\hline 3 & $8.3(-1)$ & $15(+1)$ & 0.84 \\
\hline 4 & $18.3(+1)$ & $15(+1)$ & 1.48 \\
\hline 5 & $13.3(0)$ & $10(0)$ & 1.09 \\
\hline 6 & $13.3(0)$ & $10(0)$ & 1.09 \\
\hline 7 & $13.3(0)$ & $10(0)$ & 1.09 \\
\hline 8 & $13.3(0)$ & $10(0)$ & \\
\hline
\end{tabular}

The answer to the independent variables, where $\mathrm{Y}$ is the KNR, can be approximated by the following polynomial shown in Eq. 1,

$$
Y=\beta_{0}+\beta_{1} X_{1}+\beta_{2} X_{2}+\beta_{11} X_{1}^{2}+\beta_{22} X_{2}^{2}+\beta_{12} X_{1} X_{2}
$$

where $\beta_{0}$ is the intercept, $\beta_{1}$ and $\beta_{2}$ are the first-order (linear) coefficients, $\beta_{11}$ and $\beta_{22}$ are the second-order (quadratic) coefficients, $\beta_{12}$ is the interactive coefficient, and $X_{1}$ and $X_{2}$ are the levels of the factors, i.e., $X_{1}$ is the variable CXE and $X_{2}$ is the variable CLE.

\section{Temperature and $\mathrm{pH}$}

A second CCD and response surface analysis were performed to assess the effect of the temperature and $\mathrm{pH}$ on the brown pulp biobleaching process when the previously standardized cocktail (with optimal proportions between enzyme extracts) were applied. The independent variables were studied at five levels $(-1.41,-1,0,+1,+1.41)$, which were defined according to a complete experimental design. A set of 12 experiments was carried out, four of which were repetitions of central points (Table 2). 
A fitting of the data, where $Y$ is the KNR, can be approximated by polynomial Eq. 1 , where in this case, $\beta_{0}$ is the intercept, $\beta_{1}$ and $\beta_{2}$ are the linear coefficients, $\beta_{11}$ and $\beta_{22}$ are the quadratic coefficients, $\beta_{12}$ is the interactive coefficient, and $X_{1}$ and $X_{2}$ are the levels of the factors, i.e., $X_{1}$ is the variable $\mathrm{pH}$ and $X_{2}$ is the variable temperature.

Table 2. Matrix (Coded Values of the Independent Variables $\mathrm{pH}$ and Temperature at Different Levels) and Experimental Data Recorded in Central Composite Design Setup for the Kappa Number Reduction of Brown Pulp

\begin{tabular}{|c|c|c|c|}
\hline \multirow{2}{*}{ Treatment } & \multicolumn{2}{|c|}{ Independent Variables } & \multirow{2}{*}{ KNR } \\
\cline { 2 - 3 } & $\mathrm{pH}$ & Temperature $\left({ }^{\circ} \mathrm{C}\right)$ & \\
\hline 1 & $4(-1)$ & $40(-1)$ & 0.86 \\
\hline 2 & $6(+1)$ & $40(-1)$ & 1.16 \\
\hline 3 & $4(-1)$ & $60(+1)$ & 0.78 \\
\hline 4 & $6(+1)$ & $60(+1)$ & 0.9 \\
\hline 5 & $3.59(-1.41)$ & $50(0)$ & 0.52 \\
\hline 6 & $6.41(+1.41)$ & $50(0)$ & 1.4 \\
\hline 7 & $5(0)$ & $35.9(-1.41)$ & 1.83 \\
\hline 8 & $5(0)$ & $64.1(+1.41)$ & 1.03 \\
\hline 9 & $5(0)$ & $50(0)$ & 1.41 \\
\hline 10 & $5(0)$ & $50(0)$ & 1.41 \\
\hline 11 & $5(0)$ & $50(0)$ & 1.41 \\
\hline 12 & $5(0)$ & $50(0)$ & 1.41 \\
\hline
\end{tabular}

\section{Hydrolysis of Lignocellulose Residues and Wastepaper Deinking}

The optimized enzymatic cocktail was used for the hydrolysis of sugarcane and barley bagasse and also the deinking of recycled office paper. Four grams of bagasse or wastepaper were treated under the standardized conditions in $20 \mathrm{~cm}$ x $30 \mathrm{~cm}$ polyethylene bags. After the bagasse treatments, the liquid samples in the polyethylene bags were used to analyze the reducing sugars (RS) content. After the wastepaper treatment, the samples were rinsed with abundant distilled water, filtered on a sieve $\left(1 \mathrm{~mm}^{2}\right)$, and used for the deinking analysis.

\section{Analytical Methods}

Enzyme assays and reducing sugars $(R S)$ dosage

The occurrence of pectinase, amylase, arabinanase, cellulase, xylanase, $\beta$ glucosidase, and laccase in the crude enzyme extracts was evaluated. The conditions for each assay are presented in Table S1. The cellulase, xylanase, pectinase, amylase, and arabinanase were measured from their natural substrates (Table S1). The mixtures were boiled for $5 \mathrm{~min}$, followed by the addition of $1 \mathrm{~mL}$ of distilled water and an absorbance measurement of aliquots of $100 \mu \mathrm{L}$, at $540 \mathrm{~nm}$. The RS released were quantified using the Miller method (Miller 1959). The enzyme activity unit was defined as the sum of the enzymes capable of releasing $1 \mu \mathrm{mol}$ of RS per minute.

The laccase activity was determined using the method outlined in Buswell et al. (1995), with a ABTS (2,2-azino-bis-3-ethylbenzothiazoline-6-sulfonic acid) $0.1 \mathrm{M}$ substrate in a sodium acetate buffer $0.1 \mathrm{M}$ at a $\mathrm{pH}$ of 5.5. Any increase in absorbance was monitored spectroscopically at a wavelength of $420 \mathrm{~nm}(\varepsilon=36,000 \mathrm{M} / \mathrm{cm})$ and a temperature of $60{ }^{\circ} \mathrm{C}$. One unit of enzyme activity was defined as the amount of biocatalyzer that oxidized $1 \mu \mathrm{mol}$ of ABTS per minute. The $\beta$-glucosidase activity was 
determined by $p$-nitrophenyl- $\beta$-D-glucopyranoside ( $p$ NPG) hydrolysis, measured at a wavelength of $405 \mathrm{~nm}$. The assay was initiated with $15 \mu \mathrm{L}$ of the crude extract added to 10 $\mu \mathrm{L}$ of McIlvaine buffer at a $\mathrm{pH}$ of 6.0 and $25 \mu \mathrm{L}$ of $p \mathrm{NPG}\left(4 \mathrm{mM}\right.$ in $\left.\mathrm{H}_{2} \mathrm{O}\right)$, and incubated for $5 \mathrm{~min}$ at a temperature of $50{ }^{\circ} \mathrm{C}$. The assay was stopped by adding $50 \mu \mathrm{L}$ of $0.2 \mathrm{M}$ $\mathrm{Na}_{2} \mathrm{CO}_{3}$ solution. The measurement was performed in a spectrophotometer at a wavelength of $405 \mathrm{~nm}$. The enzyme activity unit (U) was defined as the amount of enzyme required to hydrolyze $1 \mu \mathrm{mol}$ of the substrate per minute.

The results obtained from the bagasse hydrolysis were analyzed via RS dosage $(\mathrm{mg} / \mathrm{mL})$ as outlined in Miller (1959), in which the standard curves of glucose and xylose were used.

\section{Kappa number, brightness, and viscosity}

The Kappa number is an indicator of the lignin content or bleaching ability of a pulp. It can be defined as the amount (mL) of $0.1 \mathrm{~N} \mathrm{KMnO}_{4}$ solution consumed by $1 \mathrm{~g}$ of moisture-free pulp under the specified conditions. The Kappa number determination was carried out according to TAPPI standard T 236 om-99 (1999).

The brightness property (ISO) of pulp and paper samples was measured using Datacolor Elrepho 2000 spectrophotometer determined by ISO standards 2469:2014 (diffuse reflectance factor). The viscosity was determined according to the capillary viscometer method, TAPPI 230 om-19 (2019).

\section{Scanning Electron Microscopy (SEM)}

The changes in the surface morphology of the cellulose pulp after biobleaching were evaluated via scanning electron microscopy (SEM). The samples, namely the biobleached pulp and the control, were oven-dried at a temperature of $45^{\circ} \mathrm{C}$ overnight. Subsequently, they were assembled on a metallic stub with conductive adhesive tape. The material analysis occurred with a scanning electron microscope (Jeol, model JSM-6610LV, Tokyo, Japan).

\section{Statistical Analysis}

The experiments performed by the "one-at-a-time" procedure were conducted in duplicate, and the average and standard deviation values were reported.

The CCD experiments were fit for each response variable by means of regression methods, and an analysis of variance (ANOVA) was carried out. The significance of the regression models was evaluated at a $5 \%$ or $10 \%$ level ( $p$-values less than or equal to 0.05 or 0.1 ) depending on the experiment. The accuracy and general ability of the polynomial models could be evaluated by the coefficient of determination $\left(\mathrm{R}^{2}\right)$. The software Statistica (version 13.0, StatSoft, Tulsa, OK) was used to analyze the experimental data using residual error.

\section{RESULTS AND DISCUSSION}

\section{Enzyme Production}

Increased environmental consciousness has prompted paper manufactures to ponder new bleaching strategies, since the chlorine-based bleaching leads to the adsorbable organic halides (AOX) formation (Gangwar et al. 2014). Enzymatic deinking has attracted a great deal of research due to its high efficiency and low environmental impact. Several 
independent reports have confirmed an improvement in the strength and brightness of paper through the replacement of the chlorine compounds used in the usual bleaching process with xylanase and laccase (Raghukumar et al. 2004; Pala et al. 2006; Betini et al. 2009; Michelin et al. 2010; Peixoto-Nogueira et al. 2015; Kumar and Rani 2019).

The fungal enzyme extracts used for pulp biobleaching in this study were prepared following the description in the experimental section. The use of agricultural residues as alternative carbon sources to produce enzymes can reduce the production costs and also lower the final product price (Betini et al. 2009; Peixoto-Nogueira et al. 2015). Xylanase was found to be the dominant enzyme in the CXE extract $(30 \mathrm{U} / \mathrm{mL} \pm 2 \mathrm{U} / \mathrm{mL})$, while laccase was the dominant enzyme in the CLE extract $(1 \mathrm{U} / \mathrm{mL})$. However, since they were crude preparations, several enzymes could be found in the enzymatic extracts. In addition to laccase, CLE also contained pectinase $(0.300 \mathrm{U} / \mathrm{mL} \pm 0.030 \mathrm{U} / \mathrm{mL})$, xylanase $(0.440$ $\mathrm{U} / \mathrm{mL} \pm 0.080 \mathrm{U} / \mathrm{mL})$, amylase $(0.15 \mathrm{U} / \mathrm{mL} \pm 0.05 \mathrm{U} / \mathrm{mL})$, arabinanase $(0.308 \mathrm{U} / \mathrm{mL} \pm$ $0.036 \mathrm{U} / \mathrm{mL})$, cellulase $(0.05 \mathrm{U} / \mathrm{mL} \pm 0.005 \mathrm{U} / \mathrm{mL})$, and $\beta$-glucosidase $(0.121 \mathrm{U} / \mathrm{mL} \pm$ $0.006 \mathrm{U} / \mathrm{mL}$ ). A previous study by Heinen et al. (2017) reported CXE contained amylase $(6.50 \mathrm{U} / \mathrm{mL} \pm 0.158 \mathrm{U} / \mathrm{mL})$, pectinase $(0.191 \pm 0.017 \mathrm{U} / \mathrm{mL}), \beta$-glucosidase $(0.040 \pm 0.003$ $\mathrm{U} / \mathrm{mL})$, exo-1,4- $\beta$-glucanase $(0.255 \mathrm{U} / \mathrm{mL} \pm 0.015 \mathrm{U} / \mathrm{mL})$, and endo- $1,4-\beta$-glucanase $(0.150 \mathrm{U} / \mathrm{mL} \pm 0.014 \mathrm{U} / \mathrm{mL})$. Therefore, several enzymes that can act upon the paper pulp fibers, by breaking hemicelluloses and exposing lignins, were found in both extracts. The xylanolytic enzyme system carries out the xylan hydrolysis, and the ligninolytic enzymes, e.g., laccase, degrade the residual lignins. It is essential to break and eliminate the lignin due to their oxidation process that causes pulp yellowing (Kumar and Rani 2019).

Pulp bleaching has been reportedly enhanced with the addition of cellulase-free extracts since it can ensure the removal of the maximum amount of pentosans as well as the preservation of the physical properties of the pulp (Battan et al. 2007; Nagar et al. 2013; Campioni et al. 2019). The cellulase activity in the CLE and CXE extracts was considered low. However, it could have helped decrease the pulp viscosity during the biobleaching process tests.

\section{Optimization of the Extract Mixtures by Central Composite Design (CCD) and Response Surface Analysis}

Central composite design is a useful methodology for modeling technological processes through a small number of performed experiments compared with the "one variable at a time" approach, which implies time and error reduction as well as the economy of reagents (Adeleke et al. 2019).

A CCD investigated mixture combinations of the CLE and CXE. Previous research has shown that treatments with xylanase and laccase make the pulp more permeable and the lignins more accessible to chemicals; therefore, the usage of enzymes during bleaching processes makes it possible to reduce the amount of chemicals required by $20 \%$ (Bim and Franco 2000). Gupta et al. (2015) revealed a decrease in the kappa number by $9.5 \%$ using a cocktail of xylanase and laccase produced by Bacillus halodurans FNP135, and Bacillus sp., respectively. Barneto et al. (2011) showed a considerable reduction in the Kappa number of eucalyptus pulp (4.6 points) using a xylanase cocktail from Bacillus sp. BP7 and laccase from Trametes villosa. Virk et al. (2013) achieved a KNR of $19 \%$ when xylanase (Bacillus Halodurans) and laccase (Rheinheimera sp.) were applied to the paper pulp. Sharma et al. (2014) found that the bleaching effect was better when the xylanase and laccase were simultaneously added, and as a consequence, the amount of bleaching chemical used in the process was drastically reduced. These results stimulated the studying 
of the biobleaching effect of xylanase and laccase crude extracts (produced through fungal cultivation in wastes) as a cocktail for brown pulp biobleaching, as it would enhance the stability of the enzymes and increase process efficiency.

The CCD matrix and the experimental values obtained in terms of the KNR when CLE and CXE were applied to brown pulp are presented in Table 1. A significant linear model was generated for the response of the KNR using a multiple regression analysis on the experimental data. The significant model terms were evaluated via analysis of variance (ANOVA) and an F test (Table S2) ( $p$-value is less than or equal to 0.1). From the analysis, only the linear effects of CXE $\left(\mathrm{X}_{1}\right)$ and $\operatorname{CLE}\left(\mathrm{X}_{2}\right)$ and the interaction effect of $\mathrm{X}_{1}$ by $\mathrm{X}_{2}$ were found to be significant for the KNR. The model was reconstructed by removing the insignificant terms and is presented in Eq 2,

$$
K N R=1.108+0.287(C X E)+0.032(C L E)+0.0325(C X E)(C L E)
$$

The precision of a model can be checked by the determination coefficient $\left(\mathrm{R}^{2}\right)$. The determination coefficient $\left(\mathrm{R}^{2}\right)$ in this experiment implied that the sample variation of $99 \%$ for the KNR could be attributed to the independent variables. The model was not able to account for only $1 \%$ of the total variance. The linear terms were significant at the $10 \%$ level. Therefore, the linear model was selected in this optimization study.

The Student $t$ distribution and the corresponding $p$-value are given in Table S2. The smaller the $p$-value, the greater the significance of the corresponding coefficient. The linear terms CXE $\left(\mathrm{X}_{1}\right)$ and CLE $\left(\mathrm{X}_{2}\right)$ and the interaction $\mathrm{X}_{1}$ by $\mathrm{X}_{2}$ had a significant effect on the KNR with the $p$-value of CXE being less than 0.000, $p$-value of CLE equaling 0.07, and the $p$-value of CXE by CLE equaling 0.07, respectively. The response surface plot described by the regression model was drawn to illustrate the effects of the independent variables on the response variable. In this way, Fig. 1 shows the response surface for the KNR obtained via the first-order model.



Fig. 1. Response surface contours obtained via the first-order (linear) model calculated from a CCD to evaluate CLE and CXE together in terms of the KNR 
It could be seen that the highest amount of CXE $(18.3 \mathrm{~mL}$, which contains 611.5 units of xylanase) and any amount above $10 \mathrm{~mL}$ of CLE (1 unit of laccase per $\mathrm{mL}$ of extract) are advantageous parameters for the treatment of $4 \mathrm{~g}$ of brown pulp.

The xylanase present in the extract CXE can help to enhance the effect of bleaching by breaking the xylan network, which is a link between cellulose and lignin. Hence, during the subsequent stages, the laccase present in CLE, was than responsible on oxidizing the outstanding lignin in the pulp.

As the factorial experimental design showed a trend in which a larger volume of CXE was advantageous for the reduction of the Kappa number, some experiments with larger volumes of CXE were tested. Treatments $(4 \mathrm{~g}$ of brown pulp treated for $48 \mathrm{~h}$ at a temperature of $\left.50{ }^{\circ} \mathrm{C}\right)$ with greater volumes of CXE $(26.5 \mathrm{~mL}, 33.3 \mathrm{~mL}$, and $40 \mathrm{~mL}$, which correspond to $800 \mathrm{U}, 1000 \mathrm{U}$, and $1200 \mathrm{U}$ of xylanase, respectively), and CLE (maintained at $10 \mathrm{~mL}$, equaling 10 total laccase units) were tested. From these experiments, no significant reductions (considering standard deviation) in the Kappa number were found when compared to the treatments with $18.3 \mathrm{~mL}$ of CXE, containing $550 \mathrm{U}$ of xylanase (the maximum value in the linear model of CCD) (Table 3). This result shows that the high enzymatic dosages did not help to improve the pulp bleaching. This means that the use of an appropriate enzyme dosage in biobleaching saves money and time. Campioni et al. (2019) showed that higher amounts of xylanase extract did not help to further bleach the pulp based on the kappa number assay. Salles et al. (2005) also reported that a xylanase kraft pulp pretreatment with a higher enzyme dose was not attractive, due to decreased pulp fiber attachment.

Altogether, the performing the CCD helped formulate a mixing pattern of CXE and CLE at a ratio of 2 to $1(\mathrm{v} / \mathrm{v})$, which led to an increase in the KNR when applied to the biobleaching process of brown pulp.

Table 3. Kappa Number Reduction of Larger Volumes of Crude Xylanase Extract

\begin{tabular}{|c|c|c|c|c|c|}
\hline Treatment & CXE $(\mathrm{mL})$ & $\begin{array}{c}\text { Xylanase } \\
(\text { Total U) }\end{array}$ & CLE $(\mathrm{mL})$ & $\begin{array}{c}\text { Laccase } \\
(\text { Total U) }\end{array}$ & KNR \\
\hline 1 & 18.3 & 550 & 10 & 10 & $1.48 \pm 0.2$ \\
\hline 2 & 20.3 & 611 & 10 & 10 & $1.53 \pm 0.2$ \\
\hline 3 & 26.5 & 800 & 10 & 10 & $1.58 \pm 0.2$ \\
\hline 4 & 33.3 & 1000 & 10 & 10 & $1.58 \pm 0.2$ \\
\hline 5 & 40 & 1200 & 10 & 10 & $1.58 \pm 0.2$ \\
\hline
\end{tabular}

Note: $4 \mathrm{~g}$ of brown pulp treated for $48 \mathrm{~h}$ at a temperature of $50{ }^{\circ} \mathrm{C}$. The final volume $(50 \mathrm{~mL})$ was reached with a $0.1 \mathrm{mM}$ sodium acetate buffer at a $\mathrm{pH}$ of 5.5

\section{Time of the Brown Pulp Treatment}

Brown pulp treatments for $24 \mathrm{~h}$ and $48 \mathrm{~h}$ were tested. Table 4 shows the results for the KNR and xylanase and laccase residual activity after the treatments. The $48 \mathrm{~h}$ treatment time stood out since it presented a more significant reduction of in the Kappa number and still presented a good percentage of active enzymes during the treatment period. 
Table 4. Kappa Number Reduction as a Function of Treatment Time

\begin{tabular}{|c|c|c|c|}
\hline Time $(\mathrm{h})$ & KNR & Xylanase Residual Activity (\%) & Laccase Residual Activity (\%) \\
\hline Control -0 & 0 & 100 & 100 \\
\hline 24 & $1.05 \pm 0.2$ & 70.83 & 60 \\
\hline 48 & $1.52 \pm 0.2$ & 66.66 & 50 \\
\hline \multicolumn{2}{|c|}{ Note: $4 \mathrm{~g}$ of brown pulp treated at a temperature of $50^{\circ} \mathrm{C}$ with $18.3 \mathrm{~mL}$ of $\mathrm{CXE}$ and $10 \mathrm{~mL}$ of } \\
CLE and added $0.1 \mathrm{mM}$ sodium acetate buffer at a pH of 5.5 until $50 \mathrm{~mL}$ was reached \\
\hline
\end{tabular}

\section{Optimization of the $\mathrm{pH}$ and Temperature via Central Composite Design (CCD) and Response Surface Analysis}

Along with the pulp consistency, enzyme concentration, reaction time, and raw material, the efficiency of the enzymatic biobleaching process strongly depends upon the $\mathrm{pH}$ and temperature. Thus, the optimal $\mathrm{pH}$ and temperature for crude xylanase and laccase activity, and consequently the reduction the brown pulp Kappa number, were studied. Tests were performed with varying temperatures $\left(35.9{ }^{\circ} \mathrm{C}\right.$ to $\left.64.1^{\circ} \mathrm{C}\right)$ and $\mathrm{pH}$ values (3.6 to 6.4).

The CCD matrix and experimental values obtained in terms of the KNR when the $\mathrm{pH}$ and temperature were simultaneously tested are presented in Table 2 . The regression analysis showed a good fit of the experimental data to the second-order polynomial model. The significant model terms were evaluated via analysis of variance (ANOVA) and a F test (Table S3) ( $p$-value is less than or equal to 0.05). From the analysis, the linear effects of the $\mathrm{pH}$ and temperature and the quadratic effect of the $\mathrm{pH}$ were demonstrated as significant in terms of the KNR. The model was reconstructed by removing the insignificant terms and is presented in Eq. 3,

$$
K N R=1.364+0.208(\mathrm{pH})-0.282(\mathrm{pH})^{2}-0.184(\text { Temperature })
$$

Equation 3 reveals how the individual variables affected the KNR. The positive sign for the $\mathrm{pH}$ linear term indicated that, at first, this independent variable increased the KNR. However, the presence of a quadratic term in the model means that the effect of this variable changes when it is increased. Thus, the negative sign for the $\mathrm{pH}$ quadratic term indicated a concave curve in the model; i.e., this parameter is expected to start negatively affecting the KNR. Additionally, the negative coefficient value for the linear term of the temperature means that the increase of this factor reduces the KNR performance. The ANOVA ( $F$ test) shows that the second-order model was well adjusted to the experimental data. A determination coefficient $\left(\mathrm{R}^{2}\right)$ of 0.77 implies that the sample variation of $77 \%$ in terms of the KNR was attributed to the independent variables, and the model cannot explain approximate $23 \%$ of the total variance.

The Student t distribution and the corresponding $p$-value are given in Table S3 $\left(p_{\mathrm{pH}^{-}}\right.$

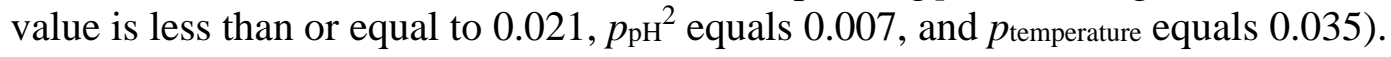

The response surface generated by the second-order model (as shown in Fig. 2) shows the influence of both variables on the KNR. It could be seen that a $\mathrm{pH}$ of 5.5 and a lower temperature $\left(36^{\circ} \mathrm{C}\right)$ are advantageous conditions for treating brown pulp.

The central composite design result showed that a temperature of $36{ }^{\circ} \mathrm{C}$ is advantageous for the brown pulp treatment with the addition of crude extracts. Thus, treatment at a temperature of $30^{\circ} \mathrm{C}$ (for $48 \mathrm{~h}$, with $4 \mathrm{~g}$ of brown pulp, with the proportions of the crude extracts selected above and a $\mathrm{pH}$ of 5.5) was performed to test if a lower temperature would result in a more effective treatment. In this experiment, no further significant reduction in the Kappa number was found; the Kappa number was 1.5 points, 
which was lower than the Kappa number found in the treatment at a temperature of $36{ }^{\circ} \mathrm{C}$. Campioni et al. (2019) described a KNR of $12.5 \%$ when xylanase produced by Trichoderma reesei QM9414 was applied to the kraft pulp biobleaching process at a temperature of $50{ }^{\circ} \mathrm{C}$ and a $\mathrm{pH}$ of 5.0. Medeiros et al. (2007) reported a KNR of 1.1 points when xylanase from Trichoderma longibrachiatum was applied to Eucalyptus kraft pulp at a temperature of $50{ }^{\circ} \mathrm{C}$ and a $\mathrm{pH}$ of 7.0.

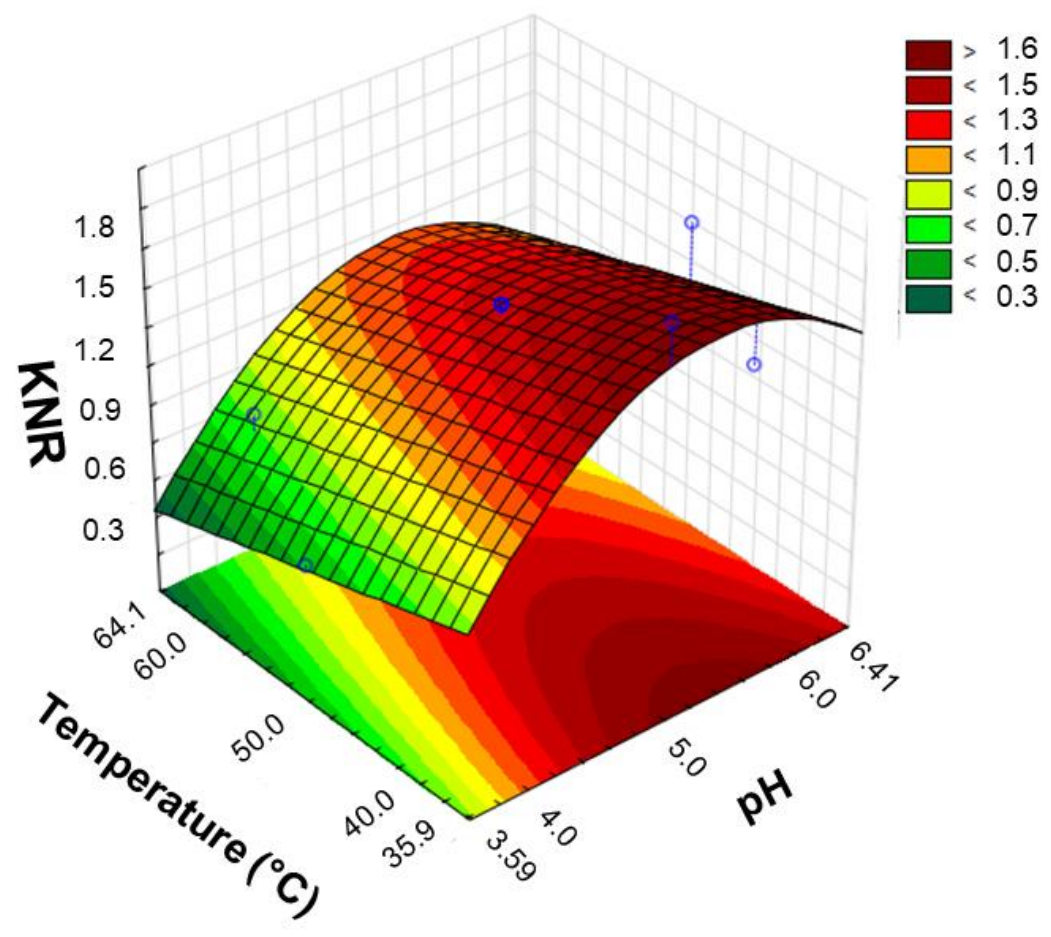

Fig. 2. Response surface contours obtained via the second-order (quadratic) model calculated from a CCD to evaluate the role of $\mathrm{pH}$ and temperature in terms of the KNR

\section{Brightness, Viscosity, and Physical Property Changes From the Biobleaching of Brown Pulp}

In this work, the most effective brown pulp biobleaching standards with the addition of an enzymatic cocktail were as follows: $18.3 \mathrm{~mL}$ of CXE and $10 \mathrm{~mL}$ of CLE for each $4 \mathrm{~g}$ of pulp, and a $48 \mathrm{~h}$ treatment time at a temperature of $36^{\circ} \mathrm{C}$, and a pH of 5.5. With these parameters, a reduction of 1.83 points in the Kappa number of the brown pulp was found, which corresponds to a Kappa efficiency of 20.3\%. Betini et al. (2009) described a Kappa efficiency of $13.10 \%$ when oxygen prebleached pulps were treated for $24 \mathrm{~h}$ with xylanase from Aspergillus japonicus - variety aculeatus (10 U/g of pulp). Rizzatti et al. (2004) described a cellulose pulp delignification efficiency of $9.30 \%$ (a Kappa number of 2.84) when treated for $1 \mathrm{~h}$ at a temperature of $50{ }^{\circ} \mathrm{C}$ of $\mathrm{pH} 5.5$ with xylanases from $A$. phoenicis (8 U/g of pulp). De Araújo et al. (1999) found a Kappa efficiency of $10.5 \%$ (a Kappa number of 11.4) in the treatment of cellulose pulp (for $3 \mathrm{~h}$ at a temperature ranging from $60{ }^{\circ} \mathrm{C}$ to $65^{\circ} \mathrm{C}$ and a $\mathrm{pH}$ of 8.0) with two commercial xylanases (Pulpzyme - Novo Nordisk and Catazyme NS-10 - Sandoz, Clariant - 0.5 U/g of pulp, respectively). PeixotoNogueira et al. (2015) described the treatment of cellulose pulp with an Aspergillus niveus xylanase $\left(10 \mathrm{U} / \mathrm{g}\right.$ of dry cellulose pulp, for $1 \mathrm{~h}$ at a temperature of $\left.70{ }^{\circ} \mathrm{C}\right)$, which resulted 
in a Kappa efficiency of $39.6 \%$, while the pulp treatment with A. niveus ligninases yielded a Kappa efficiency of 26\%. Peixoto-Nogueira et al. (2015) also described a cellulose pulp treatment with an enzymatic mix of xylanases and ligninases from A. niveus, in which the Kappa efficiency was 56\%. Michelin et al. (2010) reported a decrease of 1.1 points in the Kappa number of cellulose pulp treated with xylanase from A. terricola and an increase in brightness of 3.4. Kumar et al. (2018) achieved a brightness of approximately $10 \%$ with a cellulase and xylanase treatment.

Moreover, the brown pulp biobleaching treatment in this study also displayed a brightness (ISO) increase from 38.67 to 43.32 and reduced the viscosity from 998 to 808 . Viscosity is traditionally used to monitor cellulose pulp degradation, due to its relation to the degree of polymerization. This parameter is associated with the flow resistance imparted by the dissolved cellulose macromolecular chains. The pulp viscosity reduction found after the enzymatic treatment could be closely related to the presence of cellulases in the cocktail. Cellulases are unwanted during the first bleaching process of cellulose pulp. However, cellulases can be used to increase the additional openings/surface area of the pulp, and cellulose pulp needs to pass through refiners to be partially defibrillated before entering into a paper machine (Betini et al. 2009; Ibarra et al. 2010).

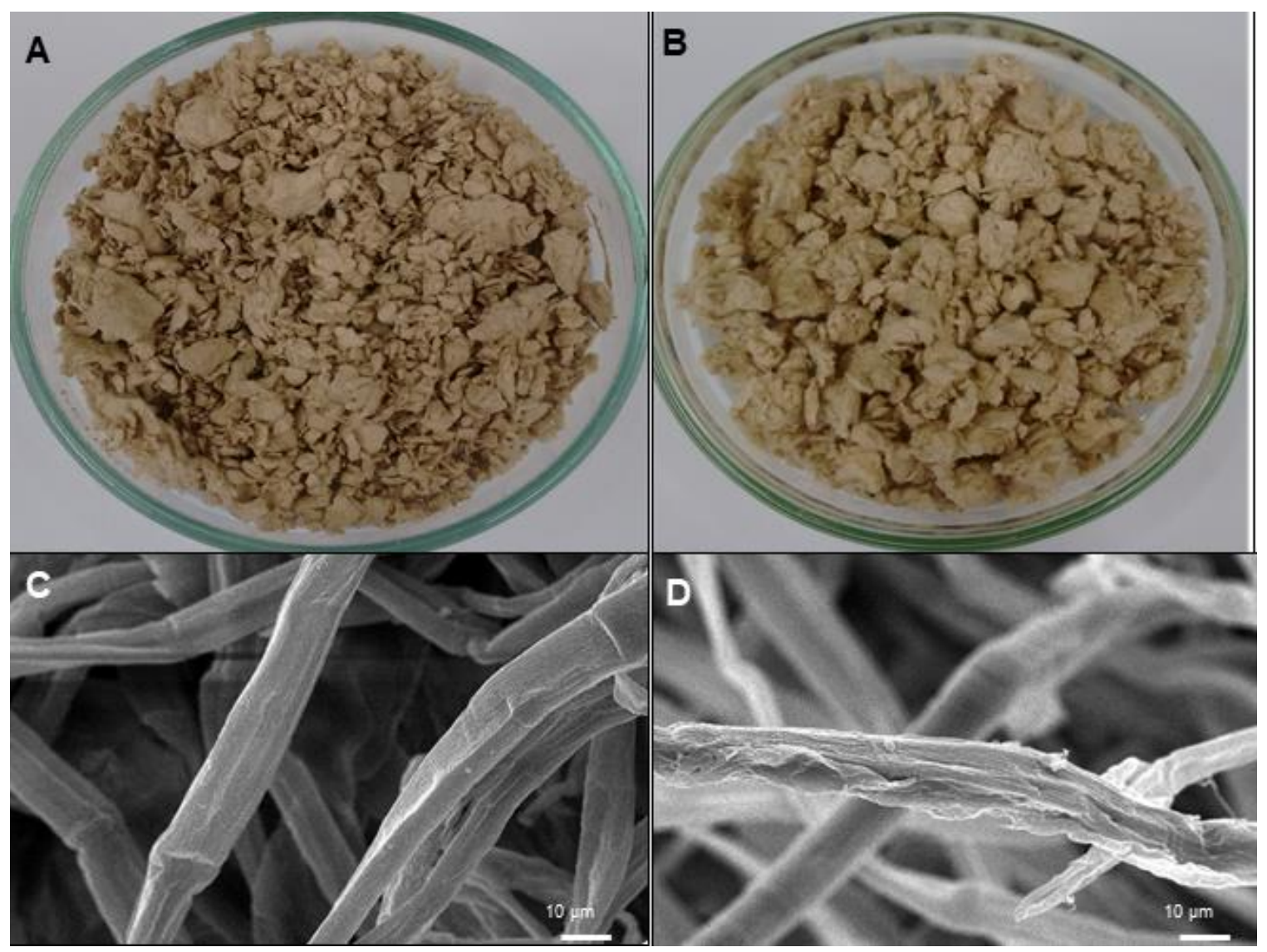

Fig. 3. Brightness and physical property changes after the biobleaching of brown pulp: (A) control pulp - untreated; (B) pulp treated with an enzymatic cocktail; (C) scanning electron microscopy of untreated brown pulp; and (D) scanning electron microscopy of pulp treated with an enzymatic cocktail 
The best-established parameters for the brown pulp biobleaching process enabled the most efficient enzymatic action present in the cocktail. It can be seen, even though there was an apparent color difference between the untreated (Fig. 3A) and treated pulp (Fig. 3B), that the second pulp was cleaner than the first one on account of the release of lignins.

The brown pulp used in the biobleaching experiments was also submitted to scanning electron microscopy (SEM) analysis. Figure 3C shows the cellulose pulp control, in which the fibers remained intact, with an integral structure. In contrast, after the enzymatic treatment (Fig. 3D), dissociation of the fibers occurred, exposing the internal polysaccharides, with morphological changes in the fiber surfaces, e.g., holes, filaments, and peels. The enzymatic treatment improved the outward degradation of hemicellulose and lignin fragments. Similar results were reported by Salles et al. (2005), Kapoor et al. (2007), Michelin et al. (2010), Peixoto-Nogueira et al. (2015), and Campioni et al. (2019). These studies also carried out scanning microscopy studies to observe the efficiency of different treatments on the cellulose pulp. The SEM analysis revealed morphological changes in all these studies, e.g., less heterogeneity and striated and rougher surfaces in the pulp fiber, after treatment using enzymes.

\section{Cocktail Application to Waste Materials and Secondary Fibers}

In addition to the replacement of chemicals during pulp bleaching, the use of waste materials, e.g., readily available lignocellulosic materials, can further reduce the economic and environmental burden of the paper and pulp industry (Lin et al. 2018). Nie et al. (2015) applied xylanase-assisted chlorine dioxide to bagasse pulp, which caused a reduction of $12.5 \%$ to $22 \%$ in the chlorine dioxide needed to achieve the same degree of brightness. Additionally, when Dai et al. (2016) tested a xylanase pretreatment on bleach bagasse pulp, the HexA and Kappa number decreased after the enzymatic treatment. Moreover, enzymes have also been related to ink removal during paper recycling. Enzymes can be as useful in deinking as chemicals (Bajpai 2012). For instance, Bobu and Ciolacu (2007) have shown that enzymes (cellulases/surfactant system) were useful in deinking toner prints.

Therefore, the efficiency of the developed cocktail was tested on non-wood cellulose sources useful for paper production. These materials were barley bagasse, sugarcane bagasse, and recycled office paper, and the hydrolysis efficiency was determined based on the formation of RS. Barley bagasse was clearly more hydrolyzed than sugarcane bagasse, with a maximum RS concentration of $85 \mathrm{mg} / \mathrm{mL}$ within $24 \mathrm{~h}$ of hydrolysis (Fig. 4); the respective maximum RS concentration for sugarcane bagasse of $25 \mathrm{mg} / \mathrm{mL}$ was obtained within $3 \mathrm{~h}$ of hydrolysis.

Barley bagasse is approximately $28 \%$ lignocellulose, while sugarcane bagasse is approximately 38\% (Monteiro 2021). The lower amount of lignins and cellulose present in the barley bagasse allowed easier access of the enzymes to the sugar polymers, since lignins confer rigidity, impermeability, and strength to the cell wall. Paper production from sugarcane bagasse is already a reality in Brazil. This process gives a sustainable fate to sugarcane bagasse, and it is an alternative to deforestation, which increased $29 \%$ in 2016 compared to 2015. On average, it is necessary for 2 to 3 tons of wood to produce one ton of paper. The first paper mill (FibraResist) using sugarcane bagasse as a raw material for paper production was built in February of 2017 in Lençóis Paulista, SP/Brazil - 22.5988 $\mathrm{S}, 48.7923^{\circ} \mathrm{W}$. The paper production in this factory occurs by applying a biodispersant, which separates the lignins from the fibers present in the bagasse (Globo-Rural 2017). In the future, this biodispersant can be replaced by enzymatic cocktails, which act by breaking down the cell wall and consequently enabling a cleaner treatment. 


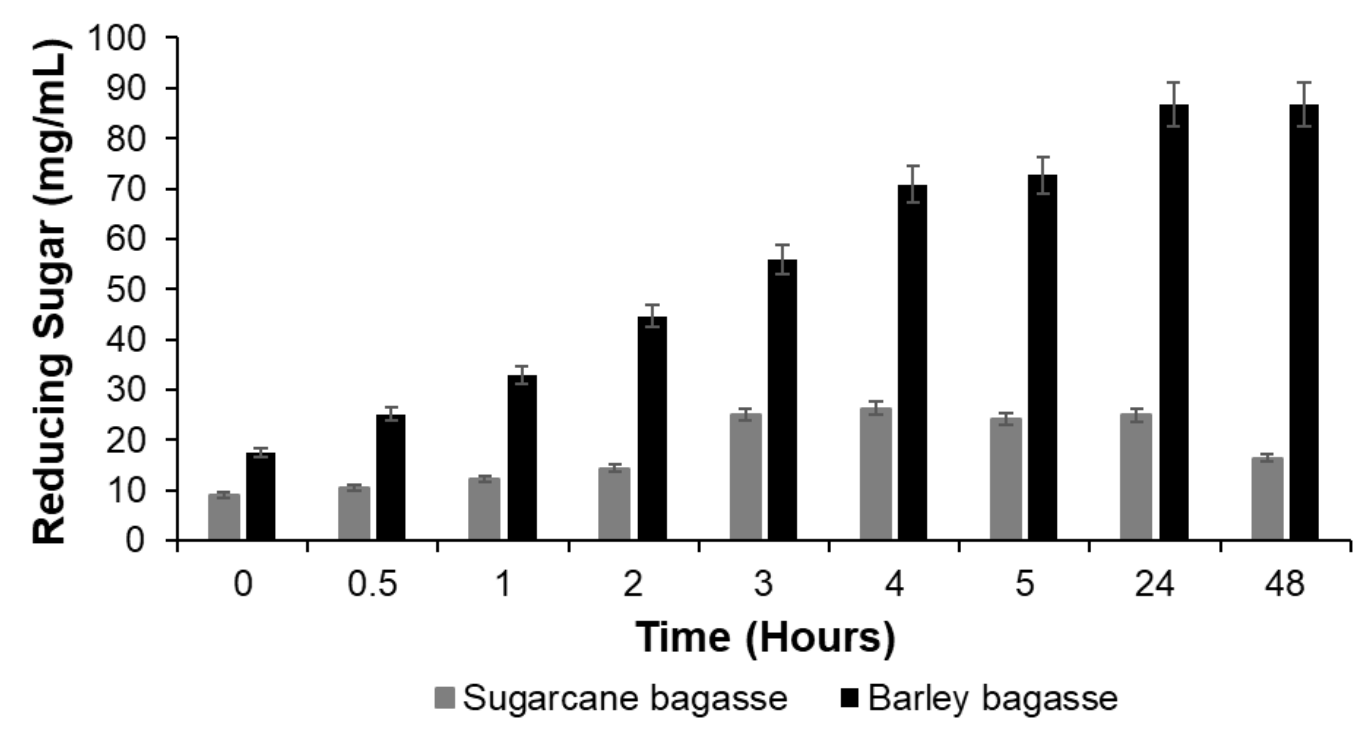

Fig. 4. The amount of RS released in the bagasse treatment with an enzymatic cocktail. (Time zero corresponds to the RS present at the beginning and treatments were developed according to the standard parameters established in this work)

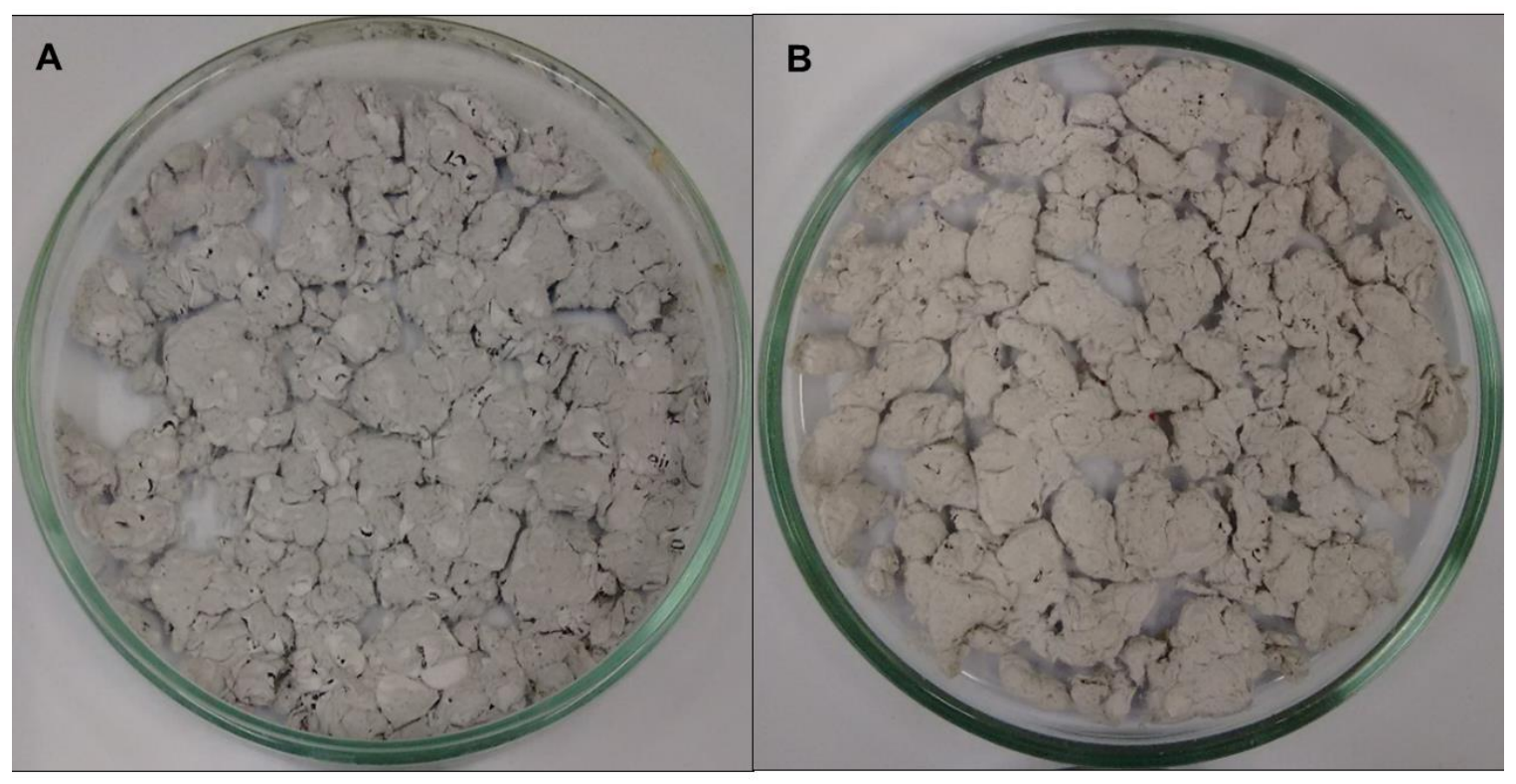

Fig. 5. Recycled office paper (secondary fibers): (A) control pulp; and (B) pulp treated with an enzymatic cocktail (treatments were developed according to the standard parameters established in this work)

The results of recycled office paper biobleaching were analyzed by means of coloration differences before and after the treatment. Figure 5 shows that the treatment caused more effective cleaning of the paper, since the control pulp had a more grayish color, while the paper pulp treated had a cleaner, lighter coloration. The enzymatic action resulted in fiber modification and, consequently, a displacement of the ink particles from 
the printing surface. The amylase present in the cocktail, for example, may have contributed to the breaking of the starch added in the refining phase of the paper.

Waste management is a great and effective alternative to achieve lower greenhouse gas emissions as well as discard solid waste. Enzyme-assisted biobleaching is somewhat safer for the environment, and it is a more straightforward option. Implementing biological bleaching can make cellulose pulp production and paper recycling eco-friendly processes (Kumar and Rani 2019). Considering the industrial need for cleaner, greener, and more cost-efficient alternatives to harmful processes, this research evaluated the use of fungal enzymes, produced through fungal cultivation in wastes (carbon sources), in the standardization of an innovative enzyme cocktail with various biotechnological applications, e.g., cellulose brown pulp bleaching, bagasse pulping, and recycled paper deinking. The use of enzyme consortia is more economically viable since, in a cocktail, enzymes can work cooperatively and synergistically, which means more effective industrial achievements.

\section{CONCLUSIONS}

1. Xylanase and laccase produced on waste materials by Aspergillus tamarii Kita and Trametes versicolor, respectively, provided promising characteristics to be industrially applied in cellulose pulp biobleaching, lignocellulosic residues hydrolysis and deinking of recycled paper pulp.

2. The optimized enzymatic cocktail facilitated the degradation of hemicelluloses and lignins in cellulose pulp and lignocellulosic residues.

3. The optimized cocktail led to (i) a Kappa efficiency of $20.3 \%$ during brown pulp treatment, (ii) formation of $85 \mathrm{~g} / \mathrm{L}$ and $25 \mathrm{~g} / \mathrm{L}$ of reducing sugars during the hydrolysis of barley residue and sugarcane bagasse, and (iii) deinked the recycled paper pulp.

4. The use of enzymatic cocktails in industrial processes can collaborate or replace highly polluting stages, e.g., in the conventional cellulose pulp bleaching process, which commonly uses several chemical compounds harmful to the environment to obtain a pulp that is free of hemicelluloses and lignins.

\section{ACKNOWLEDGMENTS}

The authors are grateful to Maurício de Oliveira and Mariana Cereia for technical assistance. This work was supported by the Fundação de Amparo à Pesquisa do Estado de São Paulo (FAPESP, processes 10/52322-3; 2014/50884-5; 2018 07522-6; and 2015/23200-0), and the Conselho Nacional de Desenvolvimento Científico e Tecnológico (CNPq processes 563260/2010-6; 465319/2014-9; and 301963/2017-7). 


\section{REFERENCES CITED}

Abdullah, R., Nisar, K., Aslam, A., Iqtedar, M., and Naz, S. (2015). "Enhanced production of xylanase from locally isolated fungal strain using agro-industrial residues under solid-state fermentation," Natural Product Research 29(11), 10061011. DOI: $10.1080 / 14786419.2014 .968157$

Adams, P. R. (1990). "Mycelial amylase activities of thermophilic species of Rhizomucor, Humicola and Papulaspora," Mycopathologia 112(1), 35-37. DOI: 10.1007/BF01795178

Adeleke, O. A., Latiff, A. A. A., Saphira, M. R., Daud, Z., Ismail, N., Ahsan, A., Ab Aziz, N. A., Ndah, M., Kumar, V., Al-Gheethi, A., et al. (2019). "Locally derived activated carbon from domestic, agricultural and industrial wastes for the treatment of palm oil mill effluent," in: Nanotechnology in Water and Wastewater Treatment, A. Ahsan and A. F. Ismail (ed.), Elsevier, Amsterdam, Netherlands, pp. 35-62.

Angural, S., Rana, M., Sharma, A., Warmoota, R., Puri, N., and Gupta, N. (2020). "Combinatorial biobleaching of mixedwood pulp with lignolytic and hemicellulolytic enzymes for paper making," Indian Journal of Microbiology 60, 383-387. DOI: 10.1007/s12088-020-00867-6

Bajpai, P. (2012). Biotechnology for Pulp and Paper Processing, Springer Nature, Basingstoke, United Kingdom.

Barneto, A. G., Valls, C., Ariza, J., and Roncero, M. B. (2011). "Thermogravimetry study of xylanase-and laccase/mediator-treated eucalyptus pulp fibres," Bioresource Technology 102(19), 9033-9039. DOI: 10.1016/j.biortech.2011.07.061

Battan, B., Sharma, J., Dhiman, S. S., and Kuhad, R. C. (2007). "Enhanced production of cellulase-free thermostable xylanase by Bacillus pumilus ASH and its potential application in paper industry," Enzyme and Microbial Technology 41(6-7), 733-739. DOI: 10.1016/j.enzmictec.2007.06.006

Betini, J. H. A., Michelin, M., Peixoto-Nogueira, S. C., Jorge, J. A., Terenzi, H. F., and Polizeli, M. L. T. M. (2009). "Xylanases from Aspergillus niger, Aspergillus niveus and Aspergillus ochraceus produced under solid-state fermentation and their application in cellulose pulp bleaching," Bioprocess and Biosystems Engineering 32(6), 819-824. DOI: 10.1007/s00449-009-0308-y

Bim, M. A., and Franco, T. T. (2000). "Extraction in aqueous two-phase systems of alkaline xylanase produced by Bacillus pumilus and its application in kraft pulp bleaching," Journal of Chromatography B: Biomedical Sciences and Applications 743(1-2), 349-356. DOI: 10.1016/S0378-4347(00)00223-1

Birijlall, N., Manimaran, A., Kumar, K. S., Permaul, K., and Singh, S. (2011). "High level expression of a recombinant xylanase by Pichia pastoris NC38 in a $5 \mathrm{~L}$ fermenter and its efficiency in biobleaching of bagasse pulp," Bioresource Technology 102(20), 9723-9729. DOI: 10.1016/j.biortech.2011.07.059

Bobu, E., and Ciolacu, F. (2007). "Environmental aspects of enzyme deinking," Wochenblat fur Papierfabrikation 1, 6-13.

Buswell, J. A., Cai, Y., and Chang, S. (1995). "Effect of nutrient nitrogen and manganese on manganese peroxidase and laccase production by Lentinula (Lentinus) edodes," FEMS Microbiology Letters 128(1), 81-87. DOI: 10.1111/j.15746968.1995.tb07504.x

Campioni, T. S., Moreira, L. d. J., Moretto, E., Nunes, N. S. S., and Neto, P. d. O. (2019). "Biobleaching of Kraft pulp using fungal xylanases produced from sugarcane straw 
and the subsequent decrease of chlorine consumption," Biomass and Bioenergy 121, 22-27. DOI: 10.1016/j.biombioe.2018.12.014

Claus, H. (2004). "Laccases: Structure, reactions, distribution," Micron 35(1-2), 93-96. DOI: $10.1016 /$ j.micron.2003.10.029

CNI (2014). "Impact study of the adoption and implementation of the Nagoya Protocol on the Brazilian Industry," Confederação Nacional da Indústria, Brasilla, Brazil.

Dai, Y., Song, X., Gao, C., He, S., Nie, S., and Qin, C. (2016). "Xylanase-aided chlorine dioxide bleaching of bagasse pulp to reduce AOX formation," BioResources 11(2), 3204-3214. DOI: 10.15376/biores.11.2.3204-3214

De Araújo, J. H. B., De Moraes, F. F., and Zanin, G. M. (1998). "Bleaching of kraft pulp with commercial xylanases," in: Proceedings of the Twentieth Symposium on Biotechnology for Fuels and Chemicals, 3-7 May, Gatlinburg, Tennessee, pp. 713722.

Ferraz, J. M. G. (2009). "O papel nosso de cada dia [Our daily role.]" Artigos TécnicosCientíficos Embrapa [Technical-Scientific Articles from Embrapa], Jaguariúna.

Ferreira-Leitão, V., Perrone, C. C., Rodrigues, J., Franke, A. P. M., Macrelli, S., and Zacchi, G. (2010). "An approach to the utilisation of $\mathrm{CO}_{2}$ as impregnating agent in steam pretreatment of sugar cane bagasse and leaves for ethanol production," Biotechnology for Biofuels 3(1), 7. DOI: 10.1186/1754-6834-3-7

Gangwar, A. K., Prakash, N. T., and Prakash, R. (2014). "Applicability of microbial xylanases in paper pulp bleaching: A review," BioResources 9(2), 3733-3754.

Globo-Rural. (2017). "Primeira fábrica que produz celulose a partir da palha da cana é inaugurada em SP [First power plant that produces cellulose from sugarcane straw opens in SP],"

(https://revistagloborural.globo.com/Noticias/Agricultura/noticia/2017/02/globorural-primeira-fabrica-que-produz-papel-a-partir-da-palha-da-cana-e-inaugurada-emsp.html), Accessed may/2020.

Gupta, V., Garg, S., Capalash, N., Gupta, N., and Sharma, P. (2015). "Production of thermo-alkali-stable laccase and xylanase by co-culturing of Bacillus sp. and $B$. halodurans for biobleaching of kraft pulp and deinking of waste paper," Bioprocess and Biosystems Engineering 38(5), 947-956. DOI: 10.1007/s00449-014-1340-0

Heinen, P. R., Pereira, M. G., Rechia, C. G. V., Almeida, P. Z., Monteiro, L. M. O., Pasin, T. M., Messias, J. M., Cereia, M., Kadowaki, M. K., Jorge, J. A., et al. (2017). "Immobilized endo-xylanase of Aspergillus tamarii Kita: An interesting biological tool for production of xylooligosaccharides at high temperatures," Process Biochemistry 53, 145-152. DOI: 10.1016/j.procbio.2016.11.021

Hubbe, M. A., Metts, J. R., Hermosilla, D., Blanco, M. A., Yerushalmi, L., Haghighat, F., Lindholm-Lehto, P., Khodaparast, Z., Kamali, M., and Elliott, A. (2016).

"Wastewater treatment and reclamation: A review of pulp and paper industry practices and opportunities," BioResources 11(3), 7953-8091. DOI:

10.15376/biores.11.3.Hubbe

Ibarra, D., Köpcke, V., and Ek, M. (2010). "Behavior of different monocomponent endoglucanases on the accessibility and reactivity of dissolving-grade pulps for viscose process," Enzyme and Microbial Technology 47(7), 355-362. DOI: 10.1016/j.enzmictec.2010.07.016

ISO 2469 (2014). "Paper, board and pulps - Measurement of diffuse radiance factor (diffuse reflectance factor)," International Organization for Standardization, Geneva, Switzerland. 
Kapoor, M., Kapoor, R. K., and Kuhad, R. C. (2007). "Differential and synergistic effects of xylanase and laccase mediator system (LMS) in bleaching of soda and waste pulps," Journal of Applied Microbiology 103(2), 305-317. DOI: 10.1111/j.13652672.2006.03251.x

Kaur, D., Bhardwaj, N. K., and Lohchab, R. K. (2018). "A study on pulping of rice straw and impact of incorporation of chlorine dioxide during bleaching on pulp properties and effluents characteristics," Journal of Cleaner Production 170, 174-182. DOI: 10.1016/j.jclepro.2017.09.111

Kumar, N. V., and Rani, M. E. (2019). "Microbial enzymes in paper and pulp industries for bioleaching application," in: Research Trends of Microbiology, MedDocs, Reno, Nevada.

Kumar, N. V., Rani, M. E., Gunaseeli, R., and Kannan, N. D. (2018). "Paper pulp modification and deinking efficiency of cellulase-xylanase complex from Escherichia coli SD5," International Journal of Biological Macromolecules 111, 289-295. DOI: 10.1016/j.ijbiomac.2017.12.126

Kumar, P., Kumar, S., Bhardwaj, N. K., and Choudhary, A. K. (2011). “Advanced oxidation of pulp and paper industry effluent," in: Proceedings of the 2011 International Conference on Environmental and Agriculture Engineering (ICEAE 2011), 29-31 July, Chengdu, China, pp. 29-31.

Lin, X., Wu, Z., Zhang, C., Liu, S., and Nie, S. (2018). "Enzymatic pulping of lignocellulosic biomass," Industrial Crops and Products 120, 16-24. DOI: 10.1016/j.indcrop.2018.04.033

Medeiros, R. G., Silva Jr, F. G. d., Báo, S. N., Hanada, R., and Filho, E. X. F. (2007). "Application of xylanases from Amazon Forest fungal species in bleaching of eucalyptus kraft pulps," Brazilian Archives of Biology and Technology 50(2), 231238. DOI: $10.1590 / \mathrm{S} 1516-89132007000200008$

Michelin, M., Peixoto-Nogueira, S. C., Betini, J. H. A., Silva, T. M.., Jorge, J. A., Terenzi, H. F., and Polizeli, M. L. T. M. (2010). "Production and properties of xylanases from Aspergillus terricola Marchal and Aspergillus ochraceus and their use in cellulose pulp bleaching," Bioprocess and Biosystems Engineering 33(7), 813-821. DOI: $10.1007 / \mathrm{s} 00449-009-0403-0$

Miller, G. L. (1959). "Use of dinitrosalicylic acid reagent for determination of reducing sugar," Analytical Chemistry 31(3), 426-428. DOI: 10.1021/ac60147a030

Monteiro, L. M. O., Vici, A. C., Messias, J. M., Heinen, P. R., Pinheiro, V. E., Rechia, C. G. V., Buckeridge, M. S., Polizeli, M.. L. T.. M. (2021). "Increased Malbranchea pulchella $\beta$-glucosidase production and its application in agroindustrial residue hydrolysis: A research based on experimental designs," Biotechnology Reports 30, e00618. DOI: 10.1016/j.btre.2021.e00618

Nagar, S., Jain, R. K., Thakur, V. V., and Gupta, V. K. (2013). "Biobleaching application of cellulase poor and alkali stable xylanase from Bacillus pumilus SV-85S," 3 Biotech 3(4), 277-285. DOI: 10.1007/s13205-012-0096-y

Nie, S., Wang, S., Qin, C., Yao, S., Ebonka, J. F., Song, X., and Li, K. (2015). "Removal of hexenuronic acid by xylanase to reduce adsorbable organic halides formation in chlorine dioxide bleaching of bagasse pulp," Bioresource Technology 196, 413-417. DOI: 10.1016/j.biortech.2015.07.115

Pala, H., Mota, M., and Gama, F. M. (2006). "Factors influencing MOW deinking: Laboratory scale studies," Enzyme and Microbial Technology 38(1-2), 81-87. DOI: 10.1016/j.enzmictec.2005.04.022 
Pasin, T. M., Almeida, P. Z.., Scarcella, A. S. A., Infante, J. C., and Polizeli, M. L. T. M. (2020). "Bioconversion of agro-industrial residues to second-generation bioethanol," in: Biorefinery of Alternative Resources: Targeting Green Fuels and Platform Chemicals, Springer, Amsterdam, Netherlands, pp. 23-47.

Peixoto-Nogueira, S. C., Betini, J. H. A., Michelin, M., Carvalho, C. C., Lucca, A. L., Vici, A. C., Jorge, J. A., and Polizeli, M. L. T. M. (2015). "Laccase production by Aspergillus niveus on SSF using wheat bran as alternative carbon source and its synergistic effect on pulp biobleaching using a mix of laccase/xylanase from the same microorganism," Journal of Biochemical Technology 6(2), 929-937.

Pinheiro, V. E., Desagiacomo, C. C. V., Michelin, M., Maller, A., Monteiro, L. M. O., Jorge, J. A., and Polizeli, M. L. T. M. (2017). "Neosartorya glabra polygalacturonase produced from fruit peels as inducers has the potential for application in passion fruit and apple juices," Brazilian Journal of Food Technology 20. DOI: 10.1590/19816723.16316

Pinheiro, V. E., Michelin, M., Vici, A. C., Almeida, P. Z., and Polizeli, M. L. T. M. (2020). "Trametes versicolor laccase production using agricultural wastes: a comparative study in Erlenmeyer flasks, bioreactor and tray," Bioprocess and Biosystems Engineering 43(3), 507-514. DOI: 10.1007/s00449-019-02245-z

Polizeli, M. L. T. M., Somera, A. F., Lucas, R. C., Nozawa, M. S. F., and Michelin, M. (2017). "Enzymes involved in the biodegradation of sugarcane biomass: challenges and perspectives," in: Advances of Basic Science for Second Generation Bioethanol from Sugarcane, Springer, Amsterdam, Netherlands, pp. 55-79.

Polizeli, M. L. T. M., Rizzatti, A. C. S., Monti, R., Terenzi, H. F., Jorge, J. A., and Amorim, D. S. (2005). "Xylanases from fungi: Properties and industrial applications," Applied Microbiology and Biotechnology 67(5), 577-591. DOI: 10.1007/s00253-005-1904-7

Raghukumar, C., Muraleedharan, U., Gaud, V. R., and Mishra, R. (2004). "Xylanases of marine fungi of potential use for biobleaching of paper pulp," Journal of Industrial Microbiology and Biotechnology 31(9), 433-441. DOI: 10.1007/s10295-004-0165-2

Rizzatti, A. C. S., Sandrim, V. C., Jorge, J. A., Terenzi, H. F., and Polizeli, M. L. T. M. (2004). "Influence of temperature on the properties of the xylanolytic enzymes of the thermotolerant fungus Aspergillus phoenicis," Journal of Industrial Microbiology and Biotechnology 31(2), 88-93. DOI: 10.1007/s10295-004-0120-2

Salles, B. C., Medeiros, R. G., Báo, S. N., Silva Jr, F. G., and Filho, E. X. F. (2005). "Effect of cellulase-free xylanases from Acrophialophora nainiana and Humicola grisea var. thermoidea on eucalyptus kraft pulp," Process Biochemistry 40(1), 343349. DOI: 10.1016/j.procbio.2004.01.008

Sharma, A., Thakur, V. V., Shrivastava, A., Jain, R. K., Mathur, R. M., Gupta, R., and Kuhad, R. C. (2014). "Xylanase and laccase based enzymatic kraft pulp bleaching reduces adsorbable organic halogen (AOX) in bleach effluents: A pilot scale study," Bioresource Technology 169, 96-102. DOI: 10.1016/j.biortech.2014.06.066

Sharma, N., Bhardwaj, N. K., and Singh, R. B. P. (2020). "Environmental issues of pulp bleaching and prospects of peracetic acid pulp bleaching: A review," Journal of Cleaner Production 256. DOI: 10.1016/j.jclepro.2020.120338

Singh, G., Kaur, S., Khatri, M., and Arya, S. K. (2019). "Biobleaching for pulp and paper industry in India: Emerging enzyme technology," Biocatalysis and Agricultural Biotechnology 17, 558-565. DOI: 10.1016/j.bcab.2019.01.019 
TAPPI 230 om-19 (2019). "Viscosity of pulp (capillary viscometer method)," TAPPI Press, Atlanta, GA.

TAPPI T 236 om-99 (1999). “Kappa number of pulp,” TAPPI Press, Atlanta, GA.

Virk, A. P., Puri, M., Gupta, V., Capalash, N., and Sharma, P. (2013). "Combined enzymatic and physical deinking methodology for efficient eco-friendly recycling of old newsprint," PLoS One 8(8), 1-8. DOI: 10.1371/journal.pone.0072346

Yang, L., Fang, L., Huang, L., Zhao, Y., and Liu, G. (2018). "Evaluating the effectiveness of using $\mathrm{ClO}_{2}$ bleaching as substitution of traditional $\mathrm{Cl}_{2}$ on $\mathrm{PCDD} / \mathrm{F}$ reduction in a non-wood pulp and paper mill using reeds as raw materials," Green Energy \& Environment 3(3), 302-308. DOI: 10.1016/j.gee.2017.07.002

Article submitted: May 13, 2021; Peer review completed: July 3, 2021; Revised version received and accepted: August 20, 2021; Published: September 24, 2021.

DOI: $10.15376 /$ biores.16.4.7509-7529 


\section{APPENDIX}

\section{Supplemental Material}

Table S1. Summary of Enzymatic Assays

\begin{tabular}{|c|c|c|c|c|}
\hline Enzyme & Substrate & $\begin{array}{c}\text { Substrate } \\
\text { Concentration }\end{array}$ & $\begin{array}{c}\text { Substrate } \\
\text { Volume }(\mu \mathrm{L})\end{array}$ & $\begin{array}{c}\text { Assay } \\
\text { Time (min) }\end{array}$ \\
\hline Xylanase $^{a}$ & beech wood xylan & $1 \%$ & 50 & 10 \\
\hline Amylase $^{a}$ & soluble potato starch & $1 \%$ & 50 & 10 \\
\hline Cellulase $^{a}$ & $\begin{array}{c}\text { medium viscosity } \\
\text { carboxymethylcellulose }\end{array}$ & $1 \%$ & 50 & 60 \\
\hline Pectinase $^{a}$ & $\begin{array}{l}\text { polygalacturonic acid } \\
\text { sodium salt }\end{array}$ & $1 \%$ & 50 & 10 \\
\hline Arabinanase ${ }^{a}$ & linear arabinan & $1 \%$ & 50 & 10 \\
\hline$\beta$-glucosidase ${ }^{b}$ & pNPG $^{d}$ & $4 \mathrm{mM}$ & 25 & 5 \\
\hline Laccase $^{c}$ & ABTS $^{e}$ & $0.1 \mathrm{M}$ & 900 & - \\
\hline \multicolumn{5}{|c|}{$\begin{array}{l}\text { a Enzymatic activity measured according to Miller (1959) } \\
\text { b Enzymatic activity measured using its artificial substrates } \\
\text { c Enzymatic activity measured according to Buswell et al. (1995) } \\
\text { d p-nitrophenyl- } \beta \text {-D-glucopyranoside } \\
\text { e 2,2-azino-bis-3-ethylbenzothiazoline-6-sulfonic acid }\end{array}$} \\
\hline
\end{tabular}

Table S2. Analysis of Variance (ANOVA) for Central Composite Design (CCD) for KNR using CXE (X1) and CLE (X2)

\begin{tabular}{|c|c|c|c|c|c|c|}
\hline Model & $\begin{array}{c}\text { Source of } \\
\text { Variation }\end{array}$ & $\begin{array}{c}\text { Sum of } \\
\text { Square }\end{array}$ & $\begin{array}{c}\text { Degrees of } \\
\text { Freedom }\end{array}$ & $\begin{array}{c}\text { Mean } \\
\text { Square }\end{array}$ & $F_{\text {cal }}$ & $p$ \\
\hline \multirow{4}{*}{ First-order } & $\mathrm{CXE}\left(\mathrm{X}_{1}\right)$ & 0.330 & 1 & 0.330 & 470.222 & $<0.000$ \\
\cline { 2 - 7 } & $\mathrm{CLE}\left(\mathrm{X}_{2}\right)$ & 0.004 & 1 & 0.004 & 6.008 & 0.070 \\
\cline { 2 - 7 } & $\mathrm{X}_{1}$ by $\mathrm{X}_{2}$ & 0.004 & 1 & 0.004 & 6.008 & 0.070 \\
\cline { 2 - 8 } & Residue & 0.002 & 4 & 0.000 & & \\
\cline { 2 - 7 } & Total $(\mathrm{T})$ & 0.341 & 7 & & \multicolumn{2}{|c|}{$\alpha=0.1$} \\
\hline
\end{tabular}

$R^{2}=0.99 ; \mathrm{F} 90 \%$

Table S3. Analysis of Variance (ANOVA) for Central Composite Design (CCD) for KNR using Different $\mathrm{pH}$ and Temperatures

\begin{tabular}{|c|c|c|c|c|c|c|}
\hline Model & $\begin{array}{c}\text { Source of } \\
\text { Variation }\end{array}$ & $\begin{array}{c}\text { Sum of } \\
\text { Square }\end{array}$ & $\begin{array}{c}\text { Degrees of } \\
\text { Freedom }\end{array}$ & $\begin{array}{c}\text { Mean } \\
\text { Square }\end{array}$ & $F_{\text {cal }}$ & $p$ \\
\hline \multirow{4}{*}{$\begin{array}{c}\text { Second- } \\
\text { order }\end{array}$} & $\begin{array}{c}\mathrm{pH}(\mathrm{X} 1) \\
\mathrm{pH}\left(\mathrm{X} 1^{2}\right)\end{array}$ & 0.345 & 1 & 0.345 & 8.205 & 0.021 \\
\cline { 2 - 7 } & $\begin{array}{c}\text { Temperature } \\
(\mathrm{X} 2)\end{array}$ & 0.528 & 1 & 0.528 & 12.541 & 0.007 \\
\cline { 2 - 8 } & \begin{tabular}{c} 
Residue \\
\cline { 2 - 7 }
\end{tabular} & 0.337 & 8 & 0.270 & 6.410 & 0.035 \\
\hline
\end{tabular}

$R^{2}=0.77 ; \mathrm{F} 95 \%$ 